In 1 the dwarf, upright, sweet, red (color here omitted) pepper is bred upon a tall, upright, hot, yellow sort. The reciprocal of this would be shown by dotted lines for the female parent. At 2 is expressed geometrically that a tall, pendent, sweet, red sort is bred upon a dwarf, upright, hot, yellow variety; and in 3 a dwarf, pendent, hot, red is the pollinator for a cross upon a tall, upright, hot yellow.

The use of symbols in plant breeding is no new thing and doubtless many workers' notebooks show various symbols that do not find their way into print. Mendel employed them freely and whole pages of Bateson's "Principles of Heredity" are literally covered with diagrammatic symbols, especially when pedigrees are visually expressed.

\title{
SPERMATOGENESIS, OR ORIGIN OF THE MALE GERM CELLS
}

\author{
L. C. Bragg and L. B. Braga \\ Fort Collins, Colo.
}

It is a well known fact that all of the higher forms of both animal and vegetable life may be traced back to the union of two cells. In plants, these two cells are designated as the pollen and ovule, in animals, egg and spermatozoon.

We hope to make plain the origin and growth of the spermatozoa of a few common insects by means of the accompanying photographs taken directly from the microscopic slides. The germ cells are early set aside in the growing embryo and are known as primitive sex cells or spermatogonia.

These cells remain dormant till the animal matures. Each cell consists of a nucleus and cytoplasm, as do most cells. The nucleus occupies the center in a membrane of its own.

All resting cells take up stains readily, so that the nucleus may be colored a deep red or black, while the outer layer of cytoplasm may be colored a beautiful green or rose tint. It is by means of these stains that we learn what is taking place during the process of transformation from the spermatogonia to the ripe spermatozoa. What is true of the animal cell is also true of the plant cell. A growing cell must soon divide and produce two. The spermatogonium grows into two spermatocytes; these again divide, forming four spermatozoa, which terminates cell division, so that each primitive cell forms ultimately four spermatozoa. 
The nucleus of the growing cell passes through four phases of growth known as the prophase, metaphase, anaphase and telophase. In the prophase, the nuclear material separates into a number of pieces

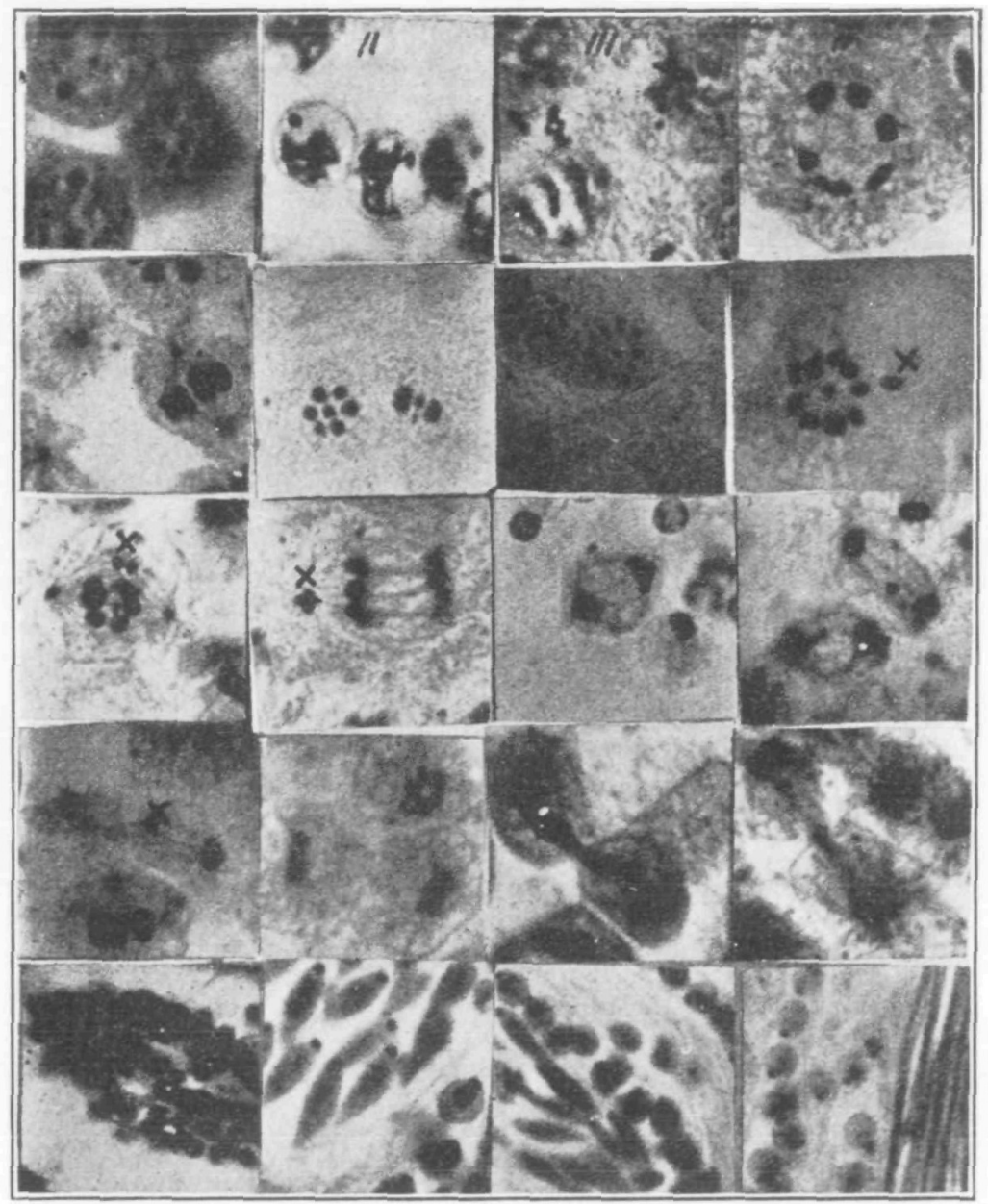

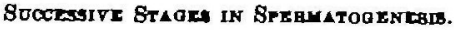

Firat line across top, prophases; second line, metaphasea; third IIne, snapheses; fourth IIne' tolephawe; fifth line, oparmatids; $x$ ex ahromasome.

called chromosomes. The nuclear wall breaks down and the chromosomes arrange themselves in a circle at the equator of the cell. This stage of growth is termed the metaphase, and when viewed from the pole of the cell the chromosomes appear as round or rod-shaped bodies forming a circle. 
Each chromosome now divides in half and the halves move toward the poles of the cell, forming the anaphase. The final step is the telophase, when they have reached the poles of the cell. A membrane now forms across the equator and the chromosomes become enclosed in a membrane, thus forming two daughter cells in the resting stage.

The chromosomes have come together and there is nothing to show their identity except in the metaphase, where they vary much in size and shape. One of these has been called the sex or $\mathrm{X}$ chromosome because in many animals the male never has this element but the female does. This gives all cells of the female one more chromosome than the male possesses in all of the somatic or body cells.

\title{
THE PRACTICAL BREEDING OF "FIRST- EARLY" MARROWFAT PEAS
}

\author{
Walter F. Giles \\ Hazeldine, Reading, England
}

To the raising of new types of garden peas there seems no end, but although the list of commercial varieties is now extremely large, it is hardly probable that the limit of improvement has yet been reached.

Year by year patient workers are endeavoring to breed something better than has hitherto been produced, by combining in a new plant the good points of the older ones, and available records show tnat in attempting to add earliness to the delicious marrowfat or wrinkledseeded peas, success has been even greater than might reasonably have been expected.

Until the early part of the nineteenth century, the garden peas in general use in England appear to have been of the round-seeded class, but as a result of some experiments in crossing carried out by Thomas Andrew Knight (a former president of the Royal Horticultural Society) one or two wrinkled types were introduced into commerce.

These new wrinkled-seeded peas, although not early nor very large in the pod, possessed a much richer flavor than the old round-seeded kinds, and came to be known as "marrowfats."

Naturally it was not long before other breeders were in the field endeavoring to improve upon Knight's introduction, with the result that many new forms with larger pods and dwarfer habit of growth were brought into cultivation. One valuable feature however which was still lacking in these improved types was earliness. None of 